Keywords: Reduction capacity, Saltstone, cement, blast furnace slag, performance assessment

Retention: Permanent

\title{
Reduction Capacity of Saltstone and Saltstone Components
}

\author{
K.A. Roberts and D.I. Kaplan
}

November, 302009

Savannah River National Laboratory Savannah River Nuclear Solutions Aiken, SC 29808

Prepared for the U.S. Department of Energy under contract number DE-AC09-08SR22470.

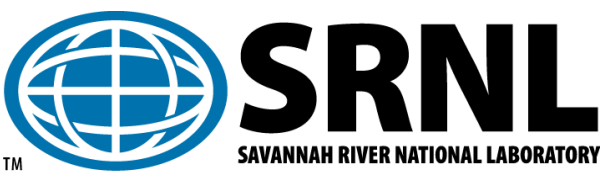


SRNL-STI-2009-00637

Revision 0

\section{DISCLAIMER}

This work was prepared under an agreement with and funded by the U.S. Government. Neither the U.S. Government or its employees, nor any of its contractors, subcontractors or their employees, makes any express or implied:

1. warranty or assumes any legal liability for the accuracy, completeness, or for the use or results of such use of any information, product, or process disclosed; or

2. representation that such use or results of such use would not infringe privately owned rights; or

3. endorsement or recommendation of any specifically identified commercial product, process, or service.

Any views and opinions of authors expressed in this work do not necessarily state or reflect those of the United States Government, or its contractors, or subcontractors.

\section{Printed in the United States of America \\ Prepared for \\ U.S. Department of Energy}




\title{
AUTHORS:
}

\section{REVIEWS AND APPROVALS}

\author{
K.A. Roberts, Radiological Performance Assessment \\ Date
}

D. I. Kaplan, Radiological Performance Assessment

Date

\section{DESIGN CHECK:}

J. R. Harbour, Engineering Processing Development

Date

\section{APPROVAL:}

H.H. Burns, Project Manager, Radiological Performance Assessment

Date

D. A. Crowley, Manager, Radiological Performance Assessment

Date

S.L. Marra, Manager

Date

Environmental \& Chemical Process Technology Research Programs

L. B. Romanowski, Customer, Savannah River Remediation, Waste Determinations Date 


\section{EXECUTIVE SUMMARY}

The duration that saltstone retains its ability to immobilize some key radionuclides, such as technetium $(\mathrm{Tc})$, plutonium $(\mathrm{Pu})$, and neptunium $(\mathrm{Np})$, depends on its capacity to maintain a low redox status (or low oxidation state). The reduction capacity is a measure of the mass of reductants present in the saltstone; the reductants are the active ingredients that immobilize Tc, $\mathrm{Pu}$, and $\mathrm{Np}$. Once reductants are exhausted, the saltstone loses its ability to immobilize these radionuclides. The reduction capacity values reported here are based on the $\mathrm{Ce}(\mathrm{IV}) / \mathrm{Fe}(\mathrm{II})$ system. The Portland cement $(198 \mu \mathrm{eq} / \mathrm{g})$ and especially the fly ash $(299 \mu \mathrm{eq} / \mathrm{g})$ had a measurable amount of reduction capacity, but the blast furnace slag $(820 \mu \mathrm{eq} / \mathrm{g})$ not surprisingly accounted for most of the reduction capacity. The blast furnace slag contains ferrous iron and sulfides which are strong reducing and precipitating species for a large number of solids. Three saltstone samples containing $45 \%$ slag or one sample containing $90 \%$ slag had essentially the same reduction capacity as pure slag. There appears to be some critical concentration between $10 \%$ and $45 \%$ slag in the Saltstone formulation that is needed to create the maximum reduction capacity. Values from this work supported those previously reported, namely that the reduction capacity of SRS saltstone is about $820 \mu \mathrm{eq} / \mathrm{g}$; this value is recommended for estimating the longevity that the Saltstone Disposal Facility will retain its ability to immobilize radionuclides. 


\section{TABLE OF CONTENTS}

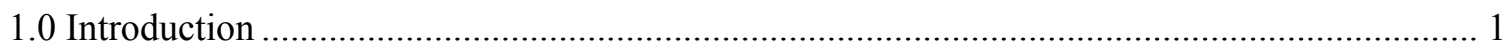

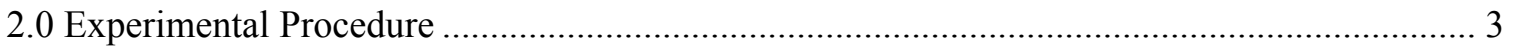

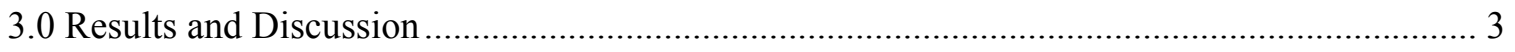

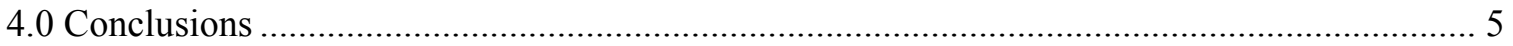

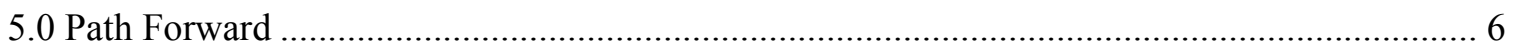

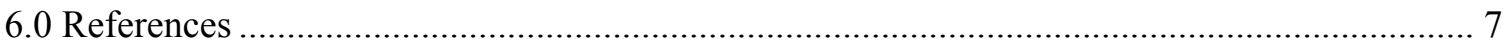

Appendix A: R\&D Directions for Reduction Capacity of a Solid ............................................... 8

Appendix B: SRNL Correspondence Document Regarding Saltstone Property Testing ............. 12

Appendix C: Methods Development for Sample Size Needed for the Ce(IV) Reduction Capacity

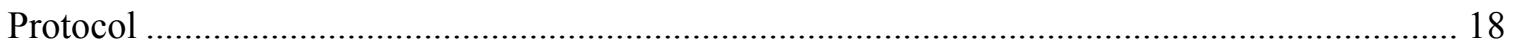




\section{LIST OF ABBREVIATIONS}

$\begin{array}{ll}\text { BFS } & \text { Blast furnace slag } \\ \text { DDA } & \text { Deliquification, Dissolution, and Adjustment } \\ \text { FA } & \text { Fly ash } \\ \text { FAS } & \text { Ferrous Ammonium Sulfate } \\ \mu \text { eq } & \text { microequivalents } \\ \text { meq } & \text { milliequivalent } \\ \text { PA } & \text { Performance Assessment } \\ \text { PC } & \text { Portland Cement } \\ \text { R and D } & \text { Research and Development } \\ \text { SRNL } & \text { Savannah River National Laboratory } \\ \text { SRS } & \text { Savannah River Site }\end{array}$




\section{LIST OF TABLES}

Table 1. Solid Sample Composition 2

Table 2. Reduction capacity ( $\mu \mathrm{eq} / \mathrm{g}$ ) of solids using the Ce(IV)- Fe(II) colorimetric titration method with $0.5 \mathrm{~g}$ of solid sample.

\section{LIST OF FIGURES}

Figure 1. Reduction capacity ( $\mu \mathrm{eq} / \mathrm{g}$ ) versus amount of blast furnace slag (\%) in solid......

Figure 2. (top) Reduction capacity of Portland cement as a function of solid concentration. (bottom) Reduction capacity of fly ash as a function of solid concentration

Figure 3. Reduction capacity of saltstone simulant as a function of solids concentration (top) TR 437 (bottom) TR547. 


\subsection{Introduction}

Savannah River Site (SRS) uses saltstone as a low level waste form in which low level liquid waste is mixed with cement, fly ash, and blast furnace slag resulting in a solid cementitious waste form. Studies on different mixtures of these components resulting in saltstone simulants are currently ongoing. The addition of blast furnace slag to these formulations is to create a reducing environment to immobilize redox sensitive radionuclides, such as Tc (technetium), $\mathrm{Pu}$ (plutonium), and $\mathrm{Np}$ (neptunium). These different formulations or simulants are being studied for their physical properties to determine efficacy in containing low level waste. The objective of this study was to measure the reduction capacity of different formulations. Additionally, reduction capacity measurements were made of saltstone components: cement, flyash and pure slag.

Angus and Glasser (1985) define the determination of reduction capacity as largely operational. They adopted the use of redox pairs $\mathrm{Ce}(\mathrm{IV}) / \mathrm{Ce}(\mathrm{III})$ and $\mathrm{Fe}(\mathrm{II}) / \mathrm{Fe}(\mathrm{III})$ to quantify reduction capacity (or poising capacity as they refer to it) for cement systems. An adaptation of this methodology is used here and thus, the reduction capacity, reported in units of microequivalents per gram of solid, refers to the ability of a simulant to reduce a given mass of $\mathrm{Ce}$ (IV) per gram of solid (the solid in this case is saltstone). Reduction capacity is one of the most important parameters for understanding risk associated with saltstone because it provides a measure for how long the Saltstone Disposal Facility will immobilize, by creating a reducing environment, some of the key risk drivers for the performance assessment (PA). The slag includes both a chemical reductant (iron(II)) and precipitating agent (sulfide) that promotes reducing conditions, lending to redox sensitive contaminants to be effectively retained in this waste form.

Previous work on the reduction capacity of saltstone simulants ${ }^{1}$ (Kaplan et al., 2008), reported the unexpected finding that DDA simulant saltstone ${ }^{2}$ which contains $23 \%$ blast furnace slag, had the same reduction capacity as $100 \%$ blast furnace slag. Several possible mechanisms were proposed including: 1) a higher $\mathrm{pH}$ in saltstone $(\mathrm{pH} \mathrm{11.8)} \mathrm{than} \mathrm{blast} \mathrm{furnace} \mathrm{slag}(\mathrm{pH} 8.1)$, resulting in the dissolution of reducing phases and increasing the saltstone reduction capacity; 2 ) semi-conductor behavior of saltstone; 3 ) increased reduction capacity of the saltstone simulant due to fly ash contributing other reducing mineral phases; and 4) saltstone may have a higher porosity than pure blast furnace slag as a result of dissolution, creating a greater surface area. Because of the many possible causes of the unexpected finding of a saltstone simulant having the same reduction capacity as blast furnace slag alone, this study evaluated the reduction capacity of four saltstone simulant formulations (TR437, TR451, TR545, TR547), a concrete sample and the three main components of saltstone (Portland cement, fly ash, and blast furnace slag). The compositions of these samples are listed in Table 1.

\footnotetext{
${ }^{1}$ Simulant refers to Saltstone without radionuclides included.

${ }^{2}$ DDA (Deliquification, Dissolution, and Adjustment) refers to the type of salt solution simulant. The saltstone formulation dry feeds ratio was $45 \%$ fly ash, $45 \%$ slag, and $10 \%$ cement, typical of most Saltstone mixtures and had a 0.6 water:premix ratio.
} 
Table 1. Solid Sample Composition

\begin{tabular}{|c|c|c|c|c|c|c|c|c|c|c|c|}
\hline Sample Number & $\begin{array}{c}\text { Blast } \\
\text { Furnace } \\
\text { Slag } \\
\end{array}$ & $\begin{array}{l}\text { Fly } \\
\text { Ash }\end{array}$ & $\begin{array}{c}\text { Portland } \\
\text { Cement }\end{array}$ & $\mathbf{W} / \mathbf{C M}$ & Simulant & Aluminate & Temp & $\begin{array}{c}\text { Admix- } \\
\text { tures }\end{array}$ & Organics & $\begin{array}{l}\text { Cast } \\
\text { Date }\end{array}$ & Comment \\
\hline & (wt- $\%)$ & (wt-\%) & (wt-\%) & & & (molarity) & ${ }^{\circ} \mathrm{C}$ & & & & \\
\hline TR437* & 45 & 45 & 10 & 0.6 & MCU & 0.054 & 22 & No & No & $3 / 31 / 08$ & \\
\hline TR451 & 45 & 45 & 10 & 0.6 & SWPF & 0.054 & 22 & No & No & $4 / 22 / 08$ & \\
\hline TR547* & 45 & 45 & 10 & 0.6 & MCU & 0.054 & 22 & No & No & $2 / 4 / 09$ & $\# 1$ \\
\hline TR431 & 45 & 45 & 10 & 0.6 & DDA & 0.054 & 22 & No & No & $3 / 18 / 08$ & $\# 2$ \\
\hline TR545* & 90 & 0 & 10 & 0.6 & MCU & 0.054 & 22 & No & No & $1 / 16 / 09$ & $\# 3$ \\
\hline Portland Cement & 0 & 0 & 100 & & & & & & & & \\
\hline $\begin{array}{l}\text { Class F Flyash } \\
\text { Blast Furnace }\end{array}$ & 0 & 100 & 0 & & & & & & & & \\
\hline Slag & 100 & 0 & 0 & & & & & & & & \\
\hline $\begin{array}{c}\text { Vault } 2 \text { Concrete } \\
\text { Aged }(30 \mathrm{yr})\end{array}$ & 10 & 6 & 0 & & & & & & & & \\
\hline concrete & 0 & 45 & 10 & & & & & & & & \\
\hline
\end{tabular}

\#1 Mix \#2 from SRNL-L3100-2009-00019

\#2 Results Reported in SRNS-STI-2008-00045

\#3 Mix \#1 from SRNL-L3100-2009-00019

* MCU Simulants identical except TR437 Nitrate $=3.32 \mathrm{M}$ and TR547/TR545 Nitrate $=3.16$. 


\subsection{Experimental Procedure}

The method used to determine the reduction capacity of the solids was adapted from Angus and Glasser (1985). As mentioned earlier, these authors define the measurement of reduction capacity as an operational one, and for quantifying reduction capacity in cement and cement blends have used the end point of the reaction $\mathrm{Fe}^{2+}+\mathrm{Ce}^{4+} \rightarrow \mathrm{Fe}^{3+}+\mathrm{Ce}^{3+}$. For this reason, such procedural steps as particle size of the sample, and contact time of the cerium with the sample may become important. Conversations with Dr. Lukens (Lawrence Berkeley National Laboratory, Berkeley, CA) who had conducted preliminary experiments evaluating contact time and chemical formulation, was helpful in refining the procedure here (details presented in Appendix A). Briefly, this method is a colorimetric titration in which a Ce(IV) solution of known concentration is made and calibrated using a reducing iron solution (FAS or ferrous ammonium sulfate). The Ce(IV) solution is added to each solid and titrated against the FAS. The difference between the reduction of $\mathrm{Ce}$ (IV) without and with the solid is then used to calculate the reduction capacity of each solid.

\subsection{Results and Discussion}

The results of the Ce(IV)-Fe(II) colorimetric titrations of $0.5 \mathrm{~g}$ of solid are listed in Table 2. The blast furnace slag can be used to compare with the work of others since there is no real reduction capacity standard commercially available. Our reduction capacity value of blast furnace slag of $819 \mu \mathrm{eq} / \mathrm{g}$ (Table 2) agrees well with previously reported values:

- $819 \mu \mathrm{eq} / \mathrm{g}$ (this study)

- $832 \mu \mathrm{eq} / \mathrm{g}$ (Kaplan et al., 2008),

- $817 \mu \mathrm{eq} / \mathrm{g}$ (Kaplan et al., 2005), and

- $820 \mu \mathrm{eq} / \mathrm{g}$ (Lukens et al., 2005).

Kaplan et al. (2008 and 2005) were conducted at the SRNL, but Lukens et al. (2005) was conducted with the same material at Lawrence Berkeley National Laboratory. The ingredients and recipes for these three samples were the same, but the samples were prepared at different times by different people. It should be noted that the slag is not porous and as such, it is possible that a greater reduction capacity may exist, if there is some "internal reduction capacity sites" not accessed by the Ce(IV) assay. The role of "internal reduction capacity sites" becomes less important if the system is found to have semiconductor properties, as is being commonly found in iron bearing systems (Cornell and Schwertmann 2003).

The Vault 2 concrete sample has also been measured previously. Unlike the blast furnace slag samples, the Vault 2 concrete sample reduction capacity values reported here, $178 \mu \mathrm{eq} / \mathrm{g}$, (Table 2) differed substantially, 25\%, from the previously reported value of $239 \mu \mathrm{eq} / \mathrm{g}$ (Kaplan et al. 2008). Given that the blast furnace slag values seem to be very reproducible, it seems reasonable to assume that the variability of the concrete sample may be attributable to sample variability/heterogeneity, and not analytical variability. Another possible explanation for the variability is that of adaptation of the original method. The Angus and Glasser (1985) method calls for determination of the endpoint of the reaction by measuring the potential until $1.057 \mathrm{~V}$ is reached. In this adaptation, the determination was made colorimetrically. The latter may allow for more subjective interpretation and thus more variable results. A last possibility is that of sample preparation. The solid samples were pulverized and passed through the same mesh size 
and each sample was assumed to be the same size but surface area of each sample was not measured directly.

Unlike the slag, the measurement of the reduction capacity of cementitious materials involves diffusion of the $\mathrm{Ce}(\mathrm{IV})$ solution into porous media (the slag is non-porous). For this reason we use a strong acid to facilitate the dissolution of carbonates and grind the samples into fine particles in the analysis.

Based on the chemical composition of the components in saltstone simulants, it is not surprising the Portland cement (a calcium silicate mineral phase along with other phases), had the lowest reduction capacity $(198 \mu \mathrm{eq} / \mathrm{g})$, followed by fly ash $(299 \mu \mathrm{eq} / \mathrm{g})$ and the highest component was the blast furnace slag $(819 \mu \mathrm{eq} / \mathrm{g})$, which contains both $\mathrm{Fe}^{2+}$ and various forms of sulfides. These results indicate that Portland cement and fly ash do have chemical reducing agents but the slag is still the main contributing source to the reduction capacity.

Table 2. Reduction capacity ( $\mu \mathrm{eq} / \mathrm{g}$ ) of solids using the $\mathrm{Ce}(\mathrm{IV})-\mathrm{Fe}$ (II) colorimetric titration method with $0.5 \mathrm{~g}$ of solid sample.

\begin{tabular}{||c|c|c|c||}
\hline Sample & \% Blast Furnace Slag & This Study & $\begin{array}{c}\text { Kaplan } \\
\text { et al., 2008 }\end{array}$ \\
\hline Saltstone TR437 & $45 \%$ & 849 & \\
\hline Saltstone TR451 & $45 \%$ & 793 & \\
\hline Saltstone TR547 & $45 \%$ & 607 & \\
\hline Saltstone TR431 & $45 \%$ & & $821 \pm 5$ \\
\hline Saltstone TR545 & $90 \%$ & 681 & \\
\hline Portland Cement & $0 \%$ & 198 & \\
\hline Class F Fly Ash & $0 \%$ & 299 & \\
\hline Blast Furnace Slag & $100 \%$ & 819 & $832.4 \pm 5$ \\
\hline Vault 2 Concrete & $10 \%$ & 178 & $239 \pm 31$ \\
\hline Aged (30 yr.) Cement & $0 \%$ & & $86 \pm 10$ \\
\hline
\end{tabular}

Three (TR437, TR451, TR547) of the four saltstone simulants studied had compositions of 45\% blast furnace slag, $45 \%$ fly ash, and 10\% Portland cement, and the fourth simulant (TR545) had $90 \%$ blast furnace slag and $10 \%$ cement. Based on this composition, it would be expected that the saltstone simulant with the largest blast furnace slag composition $(90 \%$, TR545) would have the highest reduction capacity. However, the results in Table 2 do not support this expectation. The three saltstone samples with $45 \%$ slag had 849,793 , and $607 \mu \mathrm{eq} / \mathrm{g}$, whereas the pure slag had $819 \mu \mathrm{eq} / \mathrm{g}$. Clearly the reduction capacity is not proportional to the amount of slag in the sample. This supports the finding by Kaplan et al. (2008).

All the saltstone reduction capacity data is presented in Figure 1, showing its relation to slag concentration in saltstone. The plot shows some low points, then at $45 \%$ slag it plateaus. What is not known is how the points connect between $10 \%$ and $45 \%$ and whether it is a gradual or steep curve.

The use of the Ce(IV)-Fe(II) system is useful for comparison with previous work as discussed previously. Because the reduction capacity values are relative to the system being used to 
quantify it, the $\mathrm{Ce}(\mathrm{IV})-\mathrm{Fe}(\mathrm{II})$ is not the only system used in the literature. Kaplan (2003) used the method developed by Lee and Batchelor (2003) based on the Cr(III/VI) couple to assess the reductive capacity of SRS soils and slag. This method, unlike the Ce(IV) method of Angus and Glasser (1985) is designed to probe only the surface reductant. Kaplan (2003; Fig 2) measured a reduction capacity for the SRS slag of $32 \mu \mathrm{eq} / \mathrm{g}$ using the $\mathrm{Cr}(\mathrm{III} / \mathrm{IV})$ assay, as compared to $820 \mu \mathrm{eq} / \mathrm{g}$ (page 3) using the $\mathrm{Ce}(\mathrm{III} / \mathrm{IV}$ ) assay. Again, this difference reflects that the $\mathrm{Cr}$ system measures only the surface reduction capacity, whereas the Ce system measures all or almost all of the reduction capacity. Serne (2006) also reported that for blast furnace slag the results of these methods are significantly different, with the Angus and Glasser (1985) method yielding results 20 times higher than the Lee and Batchelor (2003) method.

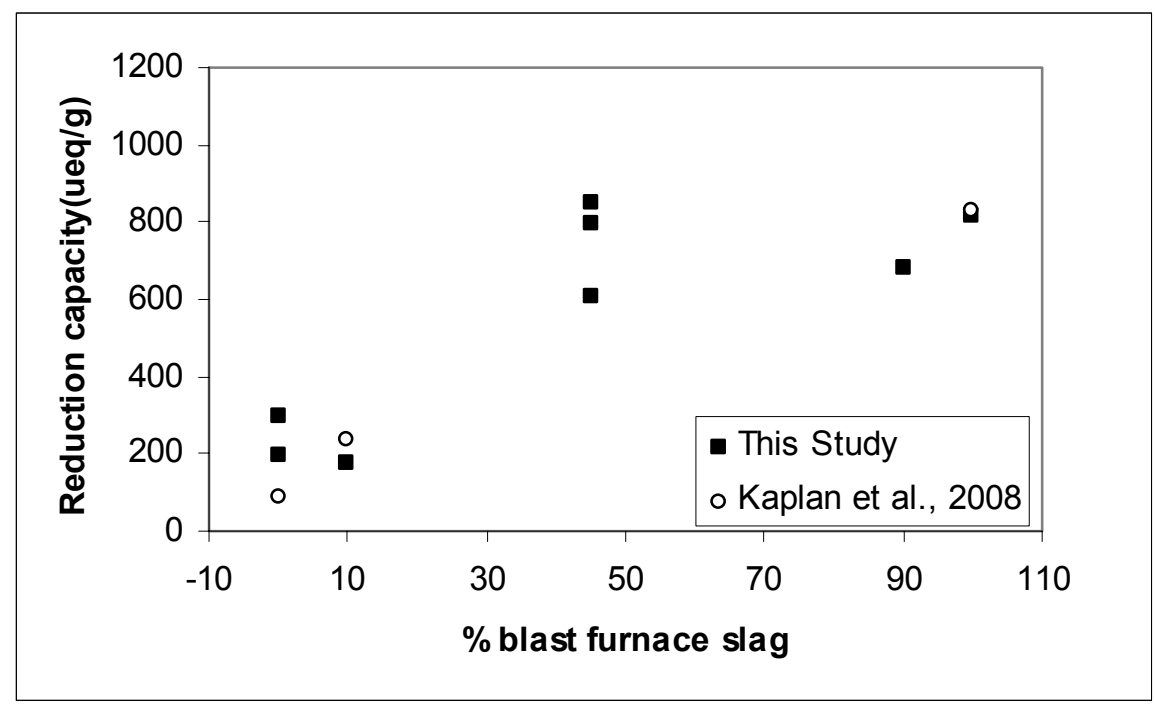

Figure 1. Reduction capacity ( $\mu \mathrm{eq} / \mathrm{g})$ versus amount of blast furnace slag (\%) in solid.

One question raised while following the Angus and Glasser method was how they came to the solid to liquid ratio used in their study. To address this, this study also investigated the reduction capacity as a function of solid concentration. This was tested as a part of methods development and part of our quality control. It confirmed that our sample size of $0.5 \mathrm{~g}$ was adequate to provide a consistent result for all types of samples. Using sample weights $<0.1 \mathrm{~g}$, results varied greatly due to different chemical reactions; at samples weights greater $\geq 0.1 \mathrm{~g}$, the results were more consistent (Appendix C). One experimental condition not addressed in this study is the role of kinetics to reduction capacity measurements. These experiments were conducted on approximately an hour of mixing the Ce solution with the solid sample and it is undetermined as to whether that is sufficient time to allow the Ce to diffuse completely (i.e. in the pore solution to be reduced and back out in time to be measured).

\subsection{Conclusions}

The reduction capacity measurements made here were based on the $\mathrm{Ce}(\mathrm{IV})-\mathrm{Fe}(\mathrm{II})$ system as described by Angus and Glasser (1985). The reduction capacities of four saltstone simulants were measured to be similar to that of pure blast furnace slag. The reduction capacity was also measured of the three major solid components of saltstone, blast furnace slag, fly ash, and 
Portland cement. The Portland cement $(198 \mu \mathrm{eq} / \mathrm{g})$ and especially the fly ash $(299 \mu \mathrm{eq} / \mathrm{g})$ had a measurable amount of reduction capacity, but the blast furnace slag $(819 \mu \mathrm{eq} / \mathrm{g})$ accounted for most of the reduction capacity. The blast furnace slag contains ferrous iron and sulfides which are strong reducing and precipitating species for a large number of solids. Values from this work supported those previously reported, namely that the reduction capacity of SRS saltstone is about $820 \mu \mathrm{eq} / \mathrm{g}$; this value is recommended for estimating the longevity that the Saltstone Disposal Facility will retain its ability to immobilize radionuclides.

\subsection{References}

Angus, M. J. and F. P. Glasser. 1985. The chemical environment in cement matrices. Mat. Res. Soc. Symp. Proc. 50: 547-556.

Cornell, R. M., and U. Schwertmann, The Iron Oxides: Structure, Properties, reactions, Occurrences, and Uses. Wiley-VCH GMbH \& Co. KGaA, Bern, Switzerland.

Kaplan, D. I. 2003. Estimated Duration of the Subsurface Reducing Environment Produced by the Z-Area Saltstone Disposal Facility. WSRC-RP-2003-00362, Rev. 1. Westinghouse Savannah River Company, Aiken, SC.

Kaplan, D.I., Hang, T., Aleman, S.E. 2005. Estimated duration of the reduction capacity within a high-level waste tank. WSRC-RP-2005-01674, Rev.0. Westinghouse Savannah River Company, Aiken, SC.

Kaplan, D.I, Roberts, K.A., Coates, J., Siegfried, M., and Serkiz, S. 2008. Saltstone and concrete interactions with radionuclides: Sorption $\left(\mathrm{K}_{\mathrm{d}}\right)$, desorption, and reduction capacity measurements. SRNL-STI-2008-00045. Savannah River Nuclear Solutions, Aiken, SC

Lee, W. and Batchelor, B. 2003. Reductive capacity of natural reductants. Environ. Sci Technol. $37,535-541$

Lukens, W.W., Bucher, J.J., Shuh, D.K., Edelstein, N.M. 2005. Evolution of technetium speciation in reducing grout. Environ. Sci. Technol. 44: 237-241.

Serne, J. 2006. Technical issues on laboratory methodology to assess long-term release of contaminants from grout/cement in the vadose zone. EM20 Cement Workshop presentation. 
SRNL-STI-2009-00637

Revision 0

Appendix A: R\&D Directions for Reduction Capacity of a Solid 


\section{R\&D Directions: \\ Reduction Capacity of Solid}

Kim Roberts \& Dan Kaplan

$6 / 1 / 09$

HAP: SRNL-ECP-2007-00009

Hazards: Acids

Hazards Mitigations: Acids: Wear appropriate PPE (gloves, safety glasses)

Materials: Ferrous ammonium sulfate (FAS)

Ceric ammonium sulfate

Phenanthroline (ferroin)

Sulfuric acid

Deionized water

$10 \mathrm{~mL}$ volumetric flasks

$250 \mathrm{~mL}$ volumetric flasks

$250 \mathrm{~mL}$ Erlenmeyer flasks

$25 \mathrm{~mL}$ titrating burette

$25 \mathrm{~mL}$ volumetric pipette

pipette bulb

Saltstone simulants and components

Methods:

\section{Reduction Capacity of Solid}

(Angus and Glasser, 1985, Mat. Res. Soc. Symp. Proc. 50:547-556.)

\section{Preparation of Solutions and Samples:}

1.1 Preparation of $0.0500 \mathrm{M}\left(\mathrm{NH}_{4}\right)_{2} \mathrm{Fe}\left(\mathrm{SO}_{4}\right) \cdot 6 \mathrm{H}_{2} \mathrm{O}$ (FAS) (primary standard) in $0.71 \mathrm{M}$ $\mathrm{H}_{2} \mathrm{SO}_{4}$

- $\quad 4.902 \mathrm{~g}$ of FAS weighed into a $250 \mathrm{~mL}$ volumetric flask

- $100 \mathrm{~mL} \mathrm{H}_{2} \mathrm{O}$ and $10 \mathrm{~mL} \mathrm{H}_{2} \mathrm{SO}_{4}(17.8 \mathrm{M})$ added in quick succession

- Filled with $\mathrm{H}_{2} \mathrm{O}$

- $\quad$ Allowed to cool to RT ( 2 hours)

- $\quad$ Added $\mathrm{H}_{2} \mathrm{O}$ to make $250.0 \mathrm{~mL}$

\subsection{Preparation of $0.0608 \mathrm{M} \mathrm{Ce}(\mathrm{IV})$ solution}

- $\quad 9.615 \mathrm{~g}$ of $\left(\mathrm{NH}_{4}\right)_{4} \mathrm{Ce}\left(\mathrm{SO}_{4}\right)_{4} \cdot 2 \mathrm{H}_{2} \mathrm{O}$ weighed into a $250 \mathrm{~mL}$ volumetric flask

- $\quad$ Added $150 \mathrm{~mL} \mathrm{H}_{2} \mathrm{O}$ and $25 \mathrm{~mL} \mathrm{H}_{2} \mathrm{SO}_{4}$ in quick succession

- $\quad$ Filled flask to $250 \mathrm{~mL}$ and added a stirbar

- Magnetically stirred for 2 hours $\left(\left(\mathrm{NH}_{4}\right)_{4} \mathrm{Ce}\left(\mathrm{SO}_{4}\right)_{4} \cdot 2 \mathrm{H}_{2} \mathrm{O}\right.$ dissolves slowly $)$

- Stirbar removed and water added to make $250 \mathrm{~mL}$

- Titrated with FAS to determine the actual Ce(IV) concentration $(0.059 \mathrm{M}$, in this case) 


\subsection{Preparation of $0.025 \mathrm{M}$ Fe(o-phenanthroline) ${ }_{3}{ }^{2+}$ (aka Ferroin)}

- $\quad 0.069 \mathrm{~g}$ of $\mathrm{FeSO}_{4} \cdot 7 \mathrm{H}_{2} \mathrm{O}$ and 0.131 of 1,10 -phenanthroline weighed into a $10 \mathrm{~mL}$ volumetric flask

- $\quad \mathrm{H}_{2} \mathrm{O}$ added to make $10.0 \mathrm{~mL}$

- Dark red solution

\subsection{Preparation of Solid Samples}

- $\quad \sim 0.5 \mathrm{~g}$ of sample was added to a $250 \mathrm{~mL}$ Erlenmeyer flask equipped with a stirbar

- $\quad 25.0 \mathrm{~mL}$ of $\sim 0.05 \mathrm{M} \mathrm{Ce}(\mathrm{IV})$ solution was added by volumetric pipette

- The contents of the flask were stirred magnetically for 1 hour at room temp.

- Added $0.100 \mathrm{~mL} 0.025 \mathrm{M} \mathrm{Fe}(o \text {-phenanthroline })_{3}{ }^{2}$ (solution acquires a greenish tint)

\section{Measurements:}

\subsection{Calibration of Ce(IV) Concentration}

- $\quad 25.0 \mathrm{~mL}$ Ce (IV) solution added to a $250 \mathrm{~mL}$ Erlenmeyer flask

- Added $0.100 \mathrm{~mL}$ Ferrion indicator (solution acquires a greenish tint)

- Titrated with $0.050 \mathrm{M}\left(\mathrm{NH}_{4}\right)_{2} \mathrm{Fe}\left(\mathrm{SO}_{4}\right) \cdot 6 \mathrm{H}_{2} \mathrm{O}$ until solution remained lilac colored.

\subsection{Ce(IV) Titration of Samples}

- Titrated with $0.050 \mathrm{M}\left(\mathrm{NH}_{4}\right)_{2} \mathrm{Fe}\left(\mathrm{SO}_{4}\right) \cdot 6 \mathrm{H}_{2} \mathrm{O}$ until solution remained lilac colored

- $\quad$ During titration, solution goes from green to pale blue to lilac to pink

\section{$\underline{3 \text { Calculations: }}$}

\subsection{Ce(IV) Calibration}

- $\quad$ Ce(IV) concentration is determined from the volume of FAS added to reach endpoint

Example: $25.0 \mathrm{ml} \mathrm{Ce(IV)} \mathrm{solution} \mathrm{was} \mathrm{titrated} \mathrm{with} 0.03021 \mathrm{~L}$ of $0.050 \mathrm{M}$ FAS

$(0.03021 \mathrm{~L}) \times(0.05 \mathrm{M} \mathrm{FAS}) \times 1 \mathrm{~mol} \mathrm{Fe}(\mathrm{II}) / 1 \mathrm{~mol} \mathrm{Ce}(\mathrm{IV})=1.5 \times 10^{-3} \mathrm{~mol} \mathrm{Fe}(\mathrm{II})$

$1.5 \times 10^{-3} \mathrm{~mol} \mathrm{Fe}(\mathrm{II}) \times 1 \mathrm{~mol} \mathrm{Ce}(\mathrm{IV}) / 1 \mathrm{~mol} \mathrm{Fe}(\mathrm{II}) / 0.025 \mathrm{~L}=0.060 \mathrm{M} \mathrm{Ce}(\mathrm{IV})$

\subsection{Determining the Total Number of Oxidizing Equivalents in Ce(IV) Solutions}

- The total number of oxidizing equivalents in the Ce(IV) solution is determined from the $\mathrm{Ce}(\mathrm{IV})$ concentration established in 3.1

Example: $0.025 \mathrm{~L}$ of $\mathrm{Ce}(\mathrm{IV})$ solution titrated

$$
0.025 \mathrm{~L} \mathrm{Ce}(\mathrm{IV}) \times 0.060 \mathrm{M} \mathrm{Ce}(\mathrm{IV})=1.5105 \times 10^{-3} \text { mole e } \mathrm{Ce}(\mathrm{IV})
$$

\subsection{The Number of Reducing Equivalents of Fe(II) Needed to Neutralize Ce(IV) after it Reacts with Sample}

Example: Unknown Ce(IV) solution was titrated with $0.02202 \mathrm{~L}$ of FAS

$\mathrm{Fe}(\mathrm{II})$

$$
0.02202 \mathrm{~L} \text { FAS x } 0.050 \mathrm{M} \mathrm{Fe}(\mathrm{II}) \times(1 \mathrm{~mol} \mathrm{Fe}(\mathrm{II}) / 1 \mathrm{~mol} \mathrm{FAS})=1.101 \times 10^{-3} \text { Mole }^{-}
$$




\subsection{Determining the Reducing Equivalents in the Solid Sample}

- The reducing equivalents in the solid sample are determined from the difference between the total oxidizing equivalents in the Ce(IV) solution (3.2) and the number of reducing equivalents needed to neutralize the Ce(IV) solution after it reacted with the sample (3.3)

Example:

$1.310 \times 10^{-3}-1.101 \times 10^{-3}=4.095 \times 10^{-4}$ mole $^{-}$

\subsection{Reducing Equivalents per Gram}

- The reducing equivalents per gram are calculated by dividing the reducing equivalents in the solid sample (3.4) by the mass of the sample.

Example: The reducing equivalents in a $0.5015 \mathrm{~g}$ sample were determined to be $4.095 \times 10^{-4}$ mole e

$4.095 \times 10^{-4} / 0.5015 \mathrm{~g}$ sample $=8.16 \times 10^{-4} \mathrm{~mole} \mathrm{e}^{-} / \mathrm{g}$ or $0.816 \mathrm{meq} / \mathrm{g}$ or $816 \mu \mathrm{eq} / \mathrm{g}$ 
Appendix B:

SRNL Correspondence Document Regarding Saltstone Property Testing 
SRNL L3100-2009-00019, Rev. 0

December 16, 2008

Keywords: Performance

Permeability

Modulus

L. B. Romanowski

Waste Determinations

From: K. L. Dixon, M. A. Phifer and J. R. Harbour

\section{FY09 PA/CA Maintenance Program: Additional Saltstone Property Testing}

\section{BACKGROUND}

Additional tests have been identified for measurement of important hydraulic and physical properties of Saltstone. The initial phase of this work [1] was completed last year and the results were detailed in an internal report [2]. The proposed testing for FY09 includes measurement of saturated hydraulic conductivity, porosity, bulk density, particle density, water retention and Young's modulus of simulated Saltstone grouts. For completeness, the bleed volumes and gel times for each mix will also be measured.

The testing will be based on a projected salt solution composition for the ARP/MCU stream that will be fed to the Saltstone Production Facility over the next few years. The scope for FY09 will include testing to determine the impact of (1) admixtures, (2) organics, (3) w/cm ratio, (4) aluminate concentration, and (5) temperature of curing on the hydraulic properties of Saltstone mixes Samples of selected batches prepared as part of this task will be provided to Dan Kaplan for measurement of $\mathrm{K}_{\mathrm{d}}$ through leaching tests. The eleven mixes that will be batched and tested are detailed in Table 1. 
Table 1. The Eleven Mixes That will be Batched and Tested

\begin{tabular}{l|c|c|c|c|c|c|c}
\hline $\begin{array}{l}\text { Mix } \\
\#\end{array}$ & $\begin{array}{l}\text { Simulant } \\
\text { Type }\end{array}$ & Descriptor & w/cm & Aluminate & BFS* $^{*}$ & FA $^{*}$ & PC $^{*}$ \\
\hline 1 & ARP/MCU & ratio & molarity & wt $\%$ & wt $\%$ & wt $\%$ \\
\hline 2 & ARP/MCU & Control - BFS/PC & 0.60 & 0.054 & 90 & 0 & 10 \\
\hline 3 & ARP/MCU & Baseline & 0.60 & 0.054 & 45 & 45 & 10 \\
\hline 4 & ARP/MCU & Baseline with Admixtures & 0.60 & 0.054 & 45 & 45 & 10 \\
\hline 5 & ARP/MCU & Baseline Combo -Organics and Admixtures & 0.60 & 0.054 & 45 & 45 & 10 \\
\hline 6 & ARP/MCU & w/cm ratio impact & 0.55 & 0.054 & 45 & 45 & 10 \\
\hline 7 & ARP/MCU & w/cm ratio impact & 0.65 & 0.054 & 45 & 45 & 10 \\
\hline 8 & ARP/MCU & Impact of Aluminate & 0.55 & 0.280 & 45 & 45 & 10 \\
\hline 9 & ARP/MCU & Impact of Aluminate & 0.65 & 0.280 & 45 & 45 & 10 \\
\hline 10 & ARP/MCU & Baseline Combo and Aluminate & 0.60 & 0.280 & 45 & 45 & 10 \\
\hline 11 & ARP/MCU & Baseline Combo at 60 oC Cure Temp. & 0.60 & 0.054 & 45 & 45 & 10 \\
\hline
\end{tabular}

* BFS is Blast Furnace Slag, FA is Fly Ash and PC is Portland Cement

\section{TEST DETAILS}

\section{Test 1 Control (Mix 1)}

A control mix will be based on the baseline mix modified by exclusion of the Class $\mathrm{F}$ fly ash. Consequently, the cementitious materials premix will be a mixture of $90 \%$ blast furnace slag and $10 \%$ portland cement. The degree of reaction will be much greater than with the normal premix and therefore should result in a lower porosity and a lower permeability. This bounding test at $0.60 \mathrm{w} / \mathrm{cm}$ ratio is expected to yield a hydraulic conductivity at or below the detection limit for the Mactec permeameter measurement system. Therefore, this test should demonstrate the lowest level of detection of the Mactec system as well as show a resolvable difference between measurements of the control mix and the control mix with the normal premix composition.

\section{Test 2 -Impact of Admixtures (Mixes 2 and 3)}

Recent Saltstone batches have required both a set retarder (Daratard 17) and an antifoam agent (Q2) for processing of the Saltstone. Therefore, the baseline mix will be prepared with and without nominal levels of these two admixtures to determine whether these admixtures appreciably affect the hydraulic and physical properties of Saltstone at these nominal concentrations.

\section{Test 3-Impact of Organics (Mixes 2 and 4)}

The solvent extraction process is expected to result in some carryover of organics [3]. 
Consequently, a test will be performed on the impact of Caustic Side Solvent Extraction (CSSX) organics at 100 microliters per 1600 gram batch. The CSSX solvent consists of 0.75 M 1-(2,2,3,3-tetrafluoropropoxy)-3-(4-sec-butylphenoxy)-2-propanol (Cs-7SB) and $0.003 \mathrm{M}$ tri-n-octylamine (TOA) in an Isopar ${ }^{\circledR} \mathrm{L}$ diluent.

\section{Test 4-Impact of Combination of Admixtures and Organics (Mixes 2, 5, 10 and 11)}

This test will determine the impact of a combination of admixtures (Test 2) and organics (Test 3 ) together in the mix vs. the baseline case without admixtures and organics.

\section{Test 5- Impact of w/cm Ratio (Mixes 2, 6 and 7)}

It is well known that decreasing the $\mathrm{w} / \mathrm{cm}$ ratio in a mix will improve permeability in normal portland cement water mixes. This test will measure the variation in permeability for the case of the MCU salt solution at three different $\mathrm{w} / \mathrm{cm}$ ratios. The initial selection of $\mathrm{w} / \mathrm{cm}$ ratios is $0.55,0.60$ and 0.65 . However, if the mix at an as-batched $0.65 \mathrm{w} / \mathrm{cm}$ ratio has significant bleed water and the resulting actual $\mathrm{w} / \mathrm{cm}$ ratio is close to 0.60 , then the three ratios will be adjusted to provide a more evenly spaced set of values. However, the baseline mix at 0.60 will be included as one of the three mixes.

\section{Test 6 - Impact of Aluminate Concentration (Mixes 8, 9 and 10)}

The DWPF has modified its process flowsheet to include a caustic washing of HLW sludge to remove some of the aluminum from the HLW prior to vitrification. The resulting aluminate stream will then be blended with tank 50 material and fed to the SPF. This increased aluminate concentration in the salt solution has significant impact on heat of hydration and set times and consequently, it is likely that it will also impact permeability. Therefore a set of three samples will be made at $\mathrm{w} / \mathrm{cm}$ ratios of $0.55,0.60$ and 0.65 (as in Test 3 ) with a higher level of aluminate $(0.28 \mathrm{M})$ for testing.

\section{Test 7 - Impact of Increased Curing Temperature (Mix 11)}

In an ongoing task, there is evidence that Young's modulus (a performance indicator) [4] is reduced by increasing the curing temperature of the mix. Since the vault temperature increases during curing as a result of the exothermic hydration reactions, one of the baseline mixes with a combination of admixtures and organics will be cured at $60{ }^{\circ} \mathrm{C}$ rather than the normal $22^{\circ} \mathrm{C}$ to determine the impact of curing temperature on the permeability. 


\section{SCHEDULE}

The schedule for the task of batching and testing of the samples is provided in Table 2 . This schedule is based on the fact that the cementitious materials will be available for the testing as needed.

Table 2 Additional Saltstone Hydraulic and Physical Property Tests

\begin{tabular}{|l|l|}
\hline Item & \multicolumn{1}{|c|}{ Schedule } \\
\hline Start Work & $12 / 1 / 08$ \\
\hline Test Plan Complete & $1 / 5 / 09$ \\
\hline Preparation of 1st set of Samples Complete & $1 / 19 / 09$ \\
\hline 90-Day Cure Period for 1st set of Samples Complete & $4 / 20 / 09$ \\
\hline
\end{tabular}


SRNL-STI-2009-00637

Revision 0

\begin{tabular}{|l|l|}
\hline $1^{\text {st }}$ set of Samples to Subcontract Laboratory & $4 / 27 / 09$ \\
\hline $\begin{array}{l}\text { Testing of } 11^{\text {th }} \text { set of Samples by Subcontract Laboratory } \\
\text { Complete }\end{array}$ & $10 / 26 / 09$ \\
\hline Draft Report Issued & $12 / 18 / 09$ \\
\hline
\end{tabular}

\section{REFERENCES}

[1] Task Technical and QA Plan: Saltstone Grout and Vault Concrete Sample Preparation and Testing, K. L. Dixon, M. A. Phifer and J. R. Harbour, WSRC-TR-2008-00037, Rev. 0, 2008

[2] Hydraulic and Physical Properties of Saltstone Grouts and Vault Concretes, K. L. Dixon, J. R. Harbour and M. A. Phifer SRNL-STI-2008-00421, Rev. 0, 2008

[3] Hydraulic and Physical Properties of MCU Saltstone, K. L. Dixon, M. A. Phifer, WSRC-STI-200700649, Rev. 0, 2007.

[4] Saltstone Performance Indicator - Dynamic Young's Modulus, J. R. Harbour and V. J. Williams, SRNL-STI-2008-00488, Rev. 0, 2008

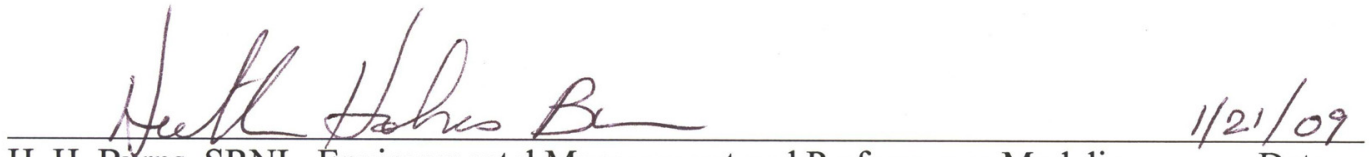

H. H. Bürns, SRNL, Environmental Management and Performance Modeling Date

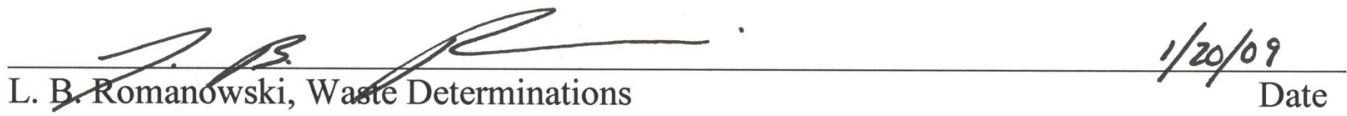


SRNL-STI-2009-00637

Revision 0

Appendix C: Methods Development for Sample Size Needed for the Ce(IV) Reduction Capacity Protocol 

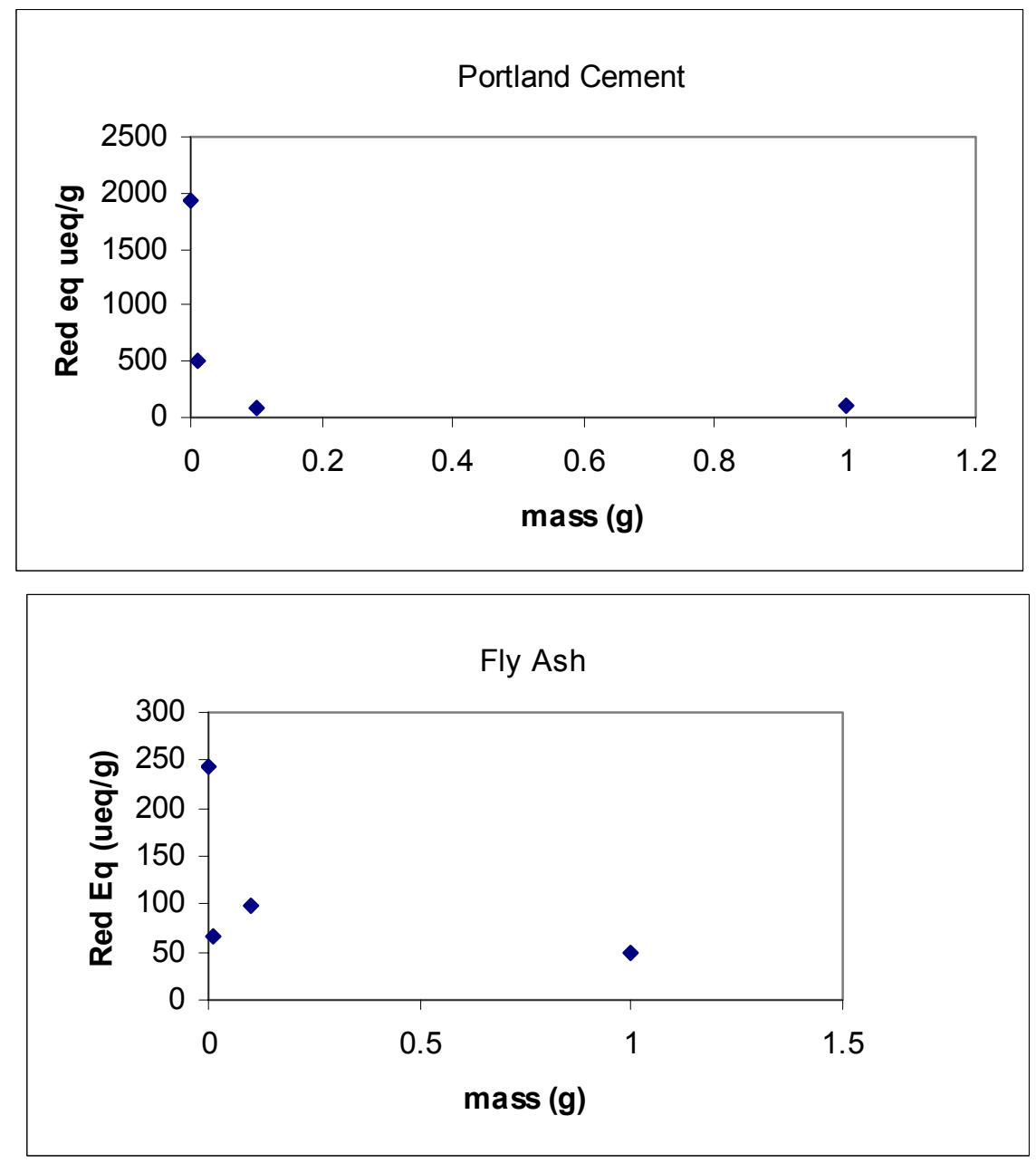

Figure 2. (top) Reduction capacity of Portland cement as a function of solid concentration. (bottom) Reduction capacity of fly ash as a function of solid concentration 
SRNL-STI-2009-00637

Revision 0
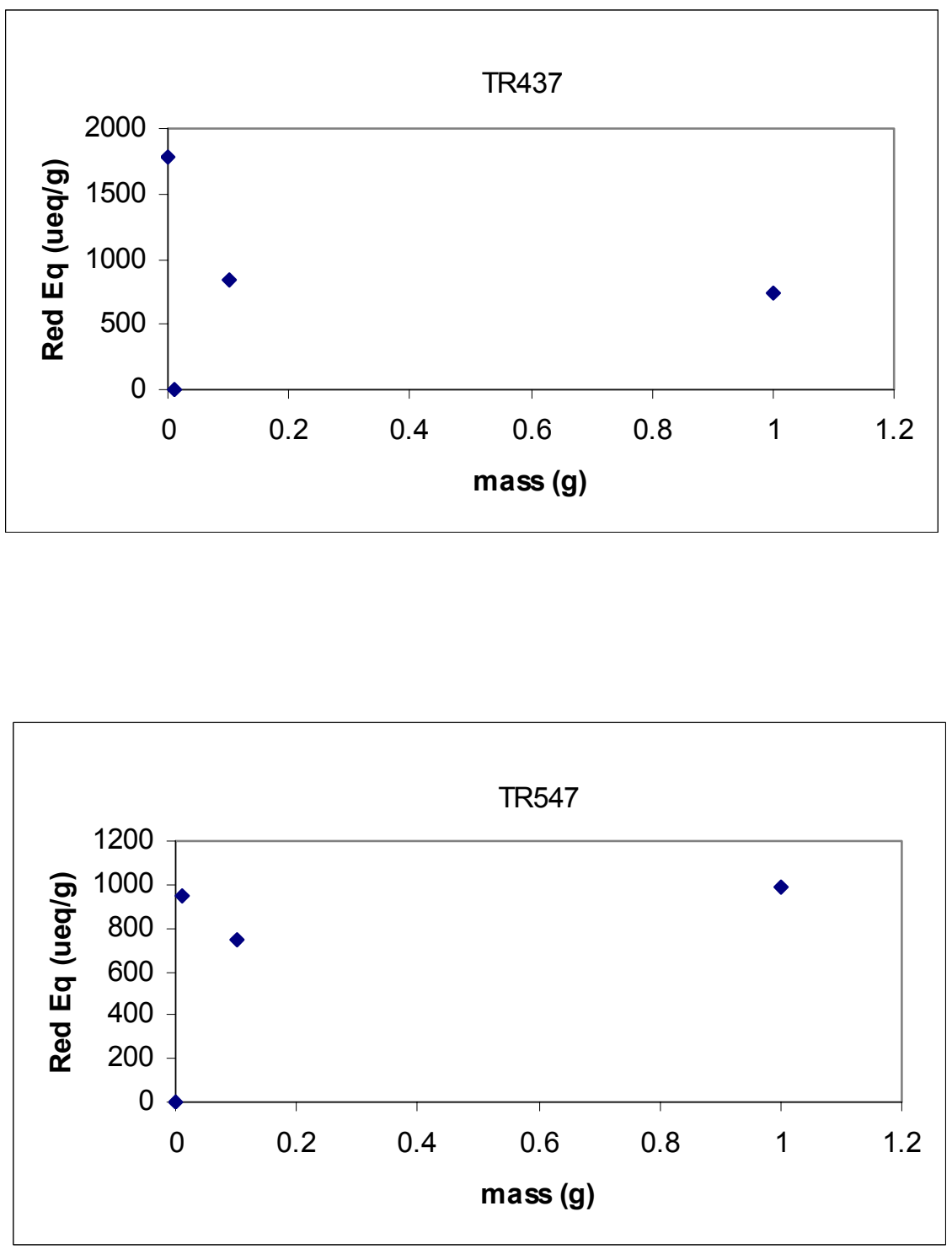

Figure 3. Reduction capacity of saltstone simulant as a function of solids concentration (top) TR 437 (bottom) TR547. 
Distribution:
A. B. Barnes
H. H. Burns
B. T. Butcher
A. D. Cozzi
D. A. Crowley
M. E. Denham
J. C. Griffin
J. R. Harbour
C. A. Langton
M. H. Layton
D. I. Kaplan (3 copies)
S. L. Marra
A. M. Murray
K. A. Roberts
T. C. Robinson
L. B. Romanowski
K. H. Rosenberger
F. M. Smith
RPA File (2 copies)

999-W, Rm. 336

999-W, Rm. 381

773-43A, Rm. 212

999-W, Rm. 337

773-43A, Rm. 216

773-42A, Rm. 218

773-A, Rm. A-231

999-W, Rm. 348

773-43A, Rm. 219

705-1C, Rm. 14

773-43A, Rm. 215

773A, Rm. A-230

773-A, Rm. 229

773-43A, Rm. 225

705-1C, Rm. 13

705-1C, Rm. 19

705-1C, Rm. 16

705-1C, Rm. 24

773-43A, Rm. 213 